\title{
MATRIK
}

Jurnal Manajemen dan Teknik Industri-Produksi

Journal homepage: http://www.journal.umg.ac.id/index.php/matriks

\section{Penjadwalan Sopir Pengangkutan Sampah Dalam Meminimalkan Ketidakmerataan Jam Kerja Di Kota Cimahi Dengan Greedy Algorithm}

\author{
Erna Mulyati ${ }^{1 *}$, Ekra Sanggala ${ }^{2}$
}

Jurusan D4 Logistik Bisnis, Politeknik Pos Indonesia

J1. Sariasih No.54, Sarijadi, Sukasari, Kota Bandung, Jawa Barat, Indonesia

ernamulyati@poltekpos.ac.id ${ }^{1 *}$, ekrasanggala@mail.ru²

\begin{tabular}{l}
\hline INFO ARTIKEL \\
\hline Jejak Artikel : \\
Upload artikel \\
30 September 2020 \\
Revisi dari reviewer \\
23 Februari 2021 \\
Publish \\
30 Maret 2021 \\
\hline
\end{tabular}

Kata Kunci :

Sampah, Penjadwalan Sopir,

Pengangkutan Sampah,

Greedy Algorithm

\section{ABSTRAK}

Sampah merupakan masalah sosial pada lingkungan masyarakat terutama pada daerah padat penduduk. Masalah yang berkaitan dengan pendistribusian sampah diantaranya adalah pengambilan keputusan mengenai rute pengangkutan sampah, biaya jadwal pengangkutan sampah termasuk didalamnya jadwal sopirnya. Penelitian ini dilakukan untuk mengatur sistem pemerataan jadwal sopir dalam pengangkutan sampah dengan menggunakan greedy algorithm untuk meminimalkan ketidakmerataan jam kerja sopir pengangkut sampah. Penelitian ini dilakukan dengan melalui empat tahapan, tahap pertama adalah pengumpulan data dan informasi terkait greedy algorithm, rute dan penjadwalan pengangkutan sampah. Tahap kedua adalah pengolahan data terkait jarak, rute, dan penentuan jadwal sopir dengan menggunakan Greedy Algorithm. Tahap ketiga adalah langkah-langkah Greedy Algorithm untuk melakukan optimalisasi pada penentuan jadwal sopir pengangkutan sampah. Hasil dari penelitian ini adalah greedy algorithm dapat dijadikan alternatif penyelesaian masalah penjadwalan sopir dalam pengangkutan sampah, karena mudah digunakan, komputasi cepat, dan memberikan hasil yang baik. Pada penelitian ini, terlihat bahwa jika menggunakan jadwal sebelumnya terjadi kesenjangan sebesar $1598 \mathrm{~km}$, sedangkan setelah dilakukan penjadwalan ulang dengan menggunakan Greedy Algorithm terjadi kesenjangan sebesar $63 \mathrm{~km}$. Tentunya ini menunjukkan terjadi penurunan kesenjangan yang cukup signifikan yaitu sebesar $1535 \mathrm{~km}$ atau sebesar 96\%. Penggunaan metode metaheuristik pada kasus penjadwalan sopir dapat menjadi penelitian selanjutnya dan diharapkan bisa memberikan hasil yang lebih baik. 


\section{Pendahuluan}

Permasalahan mengenai sampah di lingkungan masyarakat seakan tak ada habisnya, dimana sejauh ini, sampah merupakan salah satu dari sekian banyak masalah sosial yang dihadapi masyarakat di tiap daerah, terutama daerah yang padat penduduk. Hal tersebut akan berbanding lurus dengan hasil produksi jumlah sampah yang dihasilkan pada suatu daerah dengan jumlah penduduk yang tinggal didaerah tersebut. Peningkatan kualitas pengolahan sampah adalah jalan untuk menghindari adanya dampak negatif yang mungkin ditimbulkan dari keberadaan sampah. Transportasi sampah adalah suatu bagian dari sistem persampahan yaitu pengangkutan sampah dari tempat pembuangan sementara ke tempat pembuangan akhir (TPA). Masalah yang berkaitan dengan pendistribusian sampah diantaranya adalah pengambilan keputusan mengenai rute pengangkutan sampah, biaya, jadwal pengangkutan sampah termasuk didalamnya jadwal sopirnya.

Penelitian mengenai penjadwalan supir ini telah ada pada penelitian-penelitian sebelumnya. Fauziyah dan Gunawan membahas mengenai optimasi penjadwalan kerja sopir di agen perjalanan $[9,12]$. Tujuan dari penelitian tersebut adalah mengoptimasi beban kerja sopir dengan tujuan meminimumkan biaya. Metode yang digunakannya adalah integer programming dan perhitungannya dilakukann dengan bantuan software MATLAB. Azhari, Aman \& Supriyo melakukan penelitian pada penjadwalan sopir bus Transpakuan Bogor [10]. Pada penelitian tersebut bertujuan untuk menyeimbangkan jam kerja sopir. Metode yang mereka gunakan adalah integer programming. Belikha dalam penelitiannya membahas pembuatan sistem informasi penjadwalan sopir [11,13]. Penelitiannya bertujuan mengembangkan sistem informasi yang memudahkan dalam penjadwalan sopir.

Berdasarkan data Statistik [1] dijelaskan bahwa Kota Cimahi merupakan salah satu kota yang ada di Jawa Barat. Wilayah Kota Cimahi menurut UU No. 9 Tahun 2001 memiliki luas sebesar $40.25 \mathrm{Km}^{2}$. Wilayah Utara dan Barat berbatasan dengan Kabupaten Bandung dan Bandung Barat, sedangkan wilayah Selatan dan Timur berbatasan dengan Kota Bandung. Kota Cimahi terdiri dari 3 kecamatan yaitu Kecamatan Cimahi Selatan, Kecamatan Cimahi Tengah dan Kecamatan Cimahi Utara. Pada tahun 2016, jumlah wilayah administrasi kelurahan sebanyak 15 kelurahan, yang didukung oleh satuan lingkungan setempat sebanyak 312 Rukun Warga (RW) dan 1.728 Rukun Tetangga (RT). Perkembangan jumlah RW dan RT tidak signifikan sepanjang periode 2016 - 2018. Selama kurun waktu 2016-2018 jumlah penduduk Kota Cimahi mengalami peningkatan dari sebanyak 594.021 jiwa pada tahun 2016 menjadi sebanyak 601.099 jiwa di tahun 2017. Pada tahun 2018 jumlah penduduk Kota Cimahi tercatat sebanyak 607.811 jiwa. Pada periode tahun 2018 ini laju pertumbuhan penduduk sebesar 1,12 persen, dengan luas wilayah sekitar $40.25 \mathrm{~km}^{2}$, maka kepadatan penduduk tahun 2018 mencapai 15.120 jiwa/ $\mathrm{km}^{2}$ naik sebesar 1,12 persen dibandingkan dengan kondisi tahun 2017 yang mencapai 14.593 jiwa/ $\mathrm{km}^{2}$. Penambahan penduduk di Kota Cimahi datang dari berbagai sektor. Seperti warga yang pindah (pendatang), kelahiran dan kematian sehingga jumlah penduduk menjadi tinggi. Hal ini akan berdampak tentunya pada sampah yang dihasilkan dimana daerah yang padat penduduknya pasti menghasilkan sampah yang banyak. Peningkatan volume sampah pun terus meningkat seiring bertambahnya jumlah penduduk. Pada tahun 2016, rata-rata menghasilkan seberat 40 ton sampah per hari nya, sementara di tahun 2017 peningkatan volume sampah mencapai 4 kali dari volume sampah tahun sebelumnya untuk per harinya. Tentunya dengan penanggulangan yang kurang baik akan memberikan dampak buruk untuk lingkungan khususnya tentang kesehatan.

Tabel 1. Volume sampah/orang/hari

\begin{tabular}{|l|l|l|l|}
\hline No & $\begin{array}{l}\text { Satuan } \\
\text { Klasifikasi } \\
\text { Kota }\end{array}$ & $\begin{array}{l}\text { Volume } \\
\text { (liter/orang/ } \\
\text { hari) }\end{array}$ & $\begin{array}{l}\text { Berat } \\
\text { (kg/orang/hari) }\end{array}$ \\
\hline 1 & Kota sedang & $2,75-3,25$ & $0,70-0,80$ \\
\hline 2 & Kota kecil & $2,5-2,75$ & $0,625-0,70$ \\
\hline
\end{tabular}

Sumber : Sibima.pu.go.id [2]

Berdasarkan tabel 1 diketahui bahwa diperkirakan produksi sampah untuk kota sedang mencapai $0,7-0,8$ kilogram $(\mathrm{kg})$ per orang per hari sedangkan Cimahi yang termasuk kota kecil diperkirakan produksi sampahnya mencapai $0,6-0,7$ kilogram $(\mathrm{kg})$ per orang per harinya. Masalah peningkatan volume sampah menjadi polemik besar di masyarakat kota Cimahi, terutama terkait dengan kesulitan membuang sampah. Saat ini, Kota Cimahi menyediakan 20 tempat 
Pembuangan Sampah (TPS) dengan 1 TPA di TPA Sarimukti. Berikut ini adalah data jumlah produksi sampah dari 20 TPS yang berada di Kota Cimahi.

Berdasarkan tabel 2 dapat diketahui jumlah produksi sampah untuk 20 TPS dimana produksi sampah untuk tiap TPS berbeda jumlah yang diangkut oleh setiap Sopir. Dari data tabel 2 terlihat bahwa TPS Pasar kuda mengangkut setiap harinya 45 ton, kemudian TPS Pasar Atas 27 Ton dan TPS Cilember 13 ton sedangkan TPS RW 140,5 ton, TPS 11 Karya Bakti 1,5 ton dan Perum Ratulagi Baros 3 ton. Berdasarkan data tersebut dapat kita ketahui bahwa dalam satu hari sopir mengangkut sampah dengan rute yang sama, namun yang jadi permasalahan adalah beban sampah yang diangkut berbeda untuk setiap sopirnya dan ini menyebabkan ketidakmerataan beban sampah yang diangkut.

Tabel 2. Jumlah Produksi Sampah

\begin{tabular}{|c|c|c|}
\hline No & TPS & $\begin{array}{c}\text { Volume } \\
\text { Sampah (Ton) }\end{array}$ \\
\hline 1 & Cilember & 13 \\
\hline 2 & Pasar Atas & 27 \\
\hline 3 & Pasar Kuda & 45 \\
\hline 4 & Pemkot & 9 \\
\hline 5 & TPST RW 16 & 12 \\
\hline 6 & Leuwi goong & 6 \\
\hline 7 & Akses Toll Baros & 6 \\
\hline 8 & Pasar Baros & 6 \\
\hline 9 & Santiong Kolmas & 6 \\
\hline 10 & Mar - Cimol & 6 \\
\hline 11 & RW 8 Paskal & 6 \\
\hline 12 & RW 15 Cibodas & 10 \\
\hline 13 & RW 3 Cibeber & 12 \\
\hline 14 & TPST RW 14 & 6 \\
\hline 15 & Pasar Cimindi & 6 \\
\hline 16 & Perum Ratulagi Baros & 3 \\
\hline 17 & $\begin{array}{l}\text { Perum Armed Kebon } \\
\text { Rumput }\end{array}$ & 5 \\
\hline 18 & RW 14 & 0,5 \\
\hline 19 & $\begin{array}{l}\text { TPST RW } 4 \text { Patung } \\
\text { Gajah }\end{array}$ & 6 \\
\hline 20 & RW 14 Bratatex & 9 \\
\hline 21 & RW 11 Karya Bakti & 1,5 \\
\hline
\end{tabular}

Sumber : Dinas Lingkungan Hidup Kota Cimahi (2020)

Berdasarkan tabel 2 dapat diketahui jumlah produksi sampah untuk 20 TPS dimana produksi sampah untuk tiap TPS berbeda jumlah yang diangkut oleh setiap Supir. Dari data table 1.2 terlihat bahwa TPS Pasar kuda mengangkut setiap harinya 45 ton, kemudian
TPS Pasar Atas 27 Ton dan TPS Cilember 13 ton sedangkan TPS RW 140,5 ton, TPS 11 Karya Bakti 1,5 ton dan Perum Ratulagi Baros 3 ton. Berdasarkan data tersebut dapat kita ketahui bahwa dalam satu hari supir mengangkut sampah dengan rute yang sama, namun yang jadi permasalahan adalah beban sampah yang diangkut berbeda untuk setiap supirnya dan ini menyebabkan ketidakmerataan beban sampah yang diangkut.

Penelitian sebelumnya telah dilakukan di Pemkot Cimahi terkait dengan penentuan lokasi dan jumlah TPA yang optimal [3]. Penelitian berikutnya terkait masalah sampah yang terjadi di Pemkot Cimahi bukan masalah jadwal pengangkutan sampah ataupun penentuan rutenya berdasarkan kapasitas kendaraan karena rute dan jadwal pengangkutan sampah yang dilakukan di Pemkot Cimahi sudah optimal, namun pentingnya terkait dengan pengaturan sistem pemerataan jadwal sopir.

Berdasarkan permasalahan yang terjadi di Pemkot Cimahi, maka perlunya mengatur sistem pemerataan jadwal sopir. Ghiani, et al. [4] menjelaskan bahwa perlunya merancang system pengaturan sampah yang efisien, mencakup pengangkutan, pengolahan, pemusnahan sampah. Pada proses pengangkutan, salah satunya yang harus dipertimbangkan adalah masalah penjadwalan supir. Hal ini diperlukan agar beban angkut sampah untuk setiap sopir menjadi sama dan ini akan berakibat terhadap pemberian upah untuk setiap sopir yang mengangkut sampah dikota Cimahi. Pada penelitian ini volume sampah tidak berpengaruh langsung namun fenomenanya berawal dari kasus beban sampah yang diangkut oleh sopir di Cimahi saat ini yang tidak merata. Permasalahan yang mendasari dilakukannya penelitian ini adalah: bagaimana menentukan penjadwalan sopir pengangkut sampah dalam meminimalkan ketidakmerataan jam kerja di kota cimahi dengan Greedy Algorithm. Dari uraian latar belakang dan permasalahan di atas, maka tujuan penelitian ini adalah menentukan dan menganalisis penjadwalan sopir pengangkut sampah dalam meminimalkan ketidakmerataan jam kerja di kota cimahi dengan Greedy Algorithm.

Greedy Algorithm merupakan suatu teknik yang terkenal karena sangat mudah untuk mendesainnya. Greedy Algorithm ini memecahkan masalah langkah demi langkah dengan memilih pilihan terbaik yang ada pada saat itu yang disebut dengan local optimum. 
Dengan menggunakan Greedy Algorithm ini diharapkan dengan memilih local optimum di setiap langkah akan mendapatkan global optimum $[14,15]$.

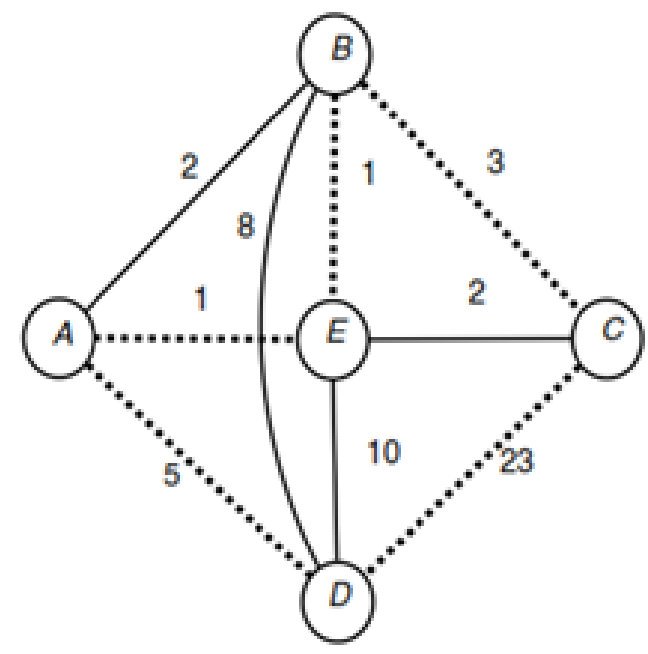

Gambar 1. Ilustrasi Pengunaan Greedy Algorithm pada TPS (Talbi [5]; Usman and Oktiarso [6])

Salah satu ilustrasi yang paling mudah untuk menjelaskan bagaimana Greedy Algorithm bekerja adalah pada penyelesaian kasus TSP. Kasus TSP ini adalah dimana ada seseorang berangkat dari kota awal harus mengunjungi sejumlah kota tepat satu kali dan berakhir dengan kembali ke kota awal. Pada gambar 1 kota awal adalah titik A, dari kota A ini terdapat 3 pilihan kota untuk dikunjungi, yaitu kota $\mathrm{B}, \mathrm{E}$ dan D. Pada gambar terlihat bahwa jarak terdekat dari kota A adalah kota $\mathrm{E}$ dengan jarak $1 \mathrm{~km}$, maka Greedy Algorithm akan memilih kota E. Dari kota E ini terdapat 3 pilihan kota, yaitu kota B, C dan D. Jarak terdekat dari kota $\mathrm{E}$ ini adalah kota $\mathrm{B}$ dengan jarak $1 \mathrm{~km}$, maka kota B akan menjadi kota selanjutnya. Cara ini terus digunakan hingga kasus TSP terselesaikan dan diperoleh rute A-E-B-C-D-A dengan jumlah jarak $33 \mathrm{~km}$.

\section{Metode Penelitian}

\subsection{Pengumpulan Data dan Informasi}

Untuk mengumpulkan data dan informasi untuk penelitian ini, dilakukan dengan studi literatur, pengambilan data dan wawancara. Langkah-langkah untuk pengumpulan data dan informasinya adalah sebagai berikut ini:

1. Studi literatur: melakukan studi literatur untuk mengetahui dan memahami bagaimana Greedy Algorithm dapat menyelesaikan suatu permasalahan optimasi.

2. Pengambilan Data, pengambilan data dilakukan di kantor Dinas Lingkungan Hidup Kota Cimahi. Data yang diambil sudah tersedia dalam bentuk file excel. Data yang tersedia pada file excel tersebut adalah data TPS, TPA, Sopir, Ritasi dan waktu pelaksanaan rute.

3. Wawancara, karena terdapat data yang diperlukan untuk penelitian ini tapi tidak tersedia pada file excel yang sudah diperoleh, maka dilakukan wawancara terhadap Kepala Dinas Lingkungan Hidup Kota Cimahi. Data yang diperoleh dari wawancara adalah data letak garasi.

4. Pencarian Data Koordinat, dengan menggunakan Google Map dicari koordinat Latitude \& Longitude untuk letak garasi, seluruh TPS dan TPA.

\subsection{Pengolahan Data}

Setelah data yang diperlukan terkumpul seluruhnya, selanjutnya perlu diolah agar dapat diselesaikan dan diperoleh solusi yang diharapkan. Adapun langkah-langkah pada pengolahan data ini adalah sebagai berikut ini:

1. Menghitung Jarak Antara Setiap Lokasi Jarak antara garasi, seluruh TPS dan TPA perlu diketahui agar dapat dihitung jarak setiap rutenya. Penghitungan jarak antara setiap lokasi ini menggunakan Harvesine Formula. Berikut ini adalah persamaan dari Harvesine formula Putra, et al. [7].

$$
\begin{gathered}
a=\sin ^{2}\left(\frac{\Delta \phi}{2}\right)+\cos \phi_{1} \cdot \cos \phi_{2} \cdot \sin ^{2}\left(\frac{\Delta \lambda}{2}\right) \\
c=2 \cdot \operatorname{atan} 2[\sqrt{a}, \sqrt{(1-a)}] \\
d=R . c
\end{gathered}
$$

dimana:

$\phi 1 \quad$ : Latitude titik pertama

$\phi 2 \quad$ : Latitude titik kedua

$\lambda 1 \quad$ : Longitude titik pertama

$\lambda 2$ : Longitude titik kedua

$\Delta \phi \quad: \phi 2-\phi 1$

$\Delta \lambda \quad: \lambda 2-\lambda 1$

$\mathrm{R} \quad$ : Radius Bumi (6371 km)

2. Penerjemahan Data Menjadi Rute

Data yang diperoleh belum memberikan informasi rute yang jelas. Oleh karena itu perlu 
dilakukan penerjemahan data menjadi rute agar bisa dilakukan pengolahan data selanjutnya.

\section{Menghitung Jarak Tempuh Setiap Sopir}

Pada tahap ini dilakukan penghitungan jarak tempuh setiap sopir berdasarkan jadwal yang sudah ditetapkan sebelumnya.

\section{Penentuan Jadwal Sopir Menggunakan Greedy Algorithm}

Pada tahap ini dilakukan optimasi penentuan jadwal sopir dengan menggunakan Greedy Algorithm. Diharapkan hasil dari optimasi ini mampu menyelesaikan permasalahan yang sudah didefinisikan.

\section{Menghitung Kesenjangan Jarak Tempuh} Sopir

Berdasarkan hasil penentuan jadwal sopir menggunakan Greedy Algorithm maka dihitung kesenjangan jarak tempuh sopir, dengan cara mengurangkan jarak tempuh terjauh dengan jarak tempuh terpendek.

\subsection{Langkah-Langkah Greedy Algorithm}

Langkah-langkah Greedy Algorithm untuk melakukan optimasi pada penentuan jadwal sopir pengangkutan sampah adalah sebagai berikut ini:

1. Menentukan Ranking Jarak Tempuh Sopir Menentukan ranking jarak tempuh sopir berdasarkan jarak tempuh yang diperoleh dari jadwal sebelumnya. Semakin jauh jarak tempuhnya maka semakin tinggi rankingnya.

2. Menentukan Ranking Rute Selanjutnya Semakin tinggi ranking jarak tempuh sopir, maka untuk rute selanjutnya, akan semakin rendah ranking rutenya.

\section{Menghitung Jarak Tempuh Sopir}

Setelah diperoleh rute selanjutnya, maka akan dihitung jumlah jarak tempuh sopir yang diakumulasikan dengan jarak tempuh rute-rute sebelumnya.

4. Penentuan Rute Selanjutnya Atau Selesai Jika masih ada rute yang belum teralokasikan maka lanjut ke langkah 1, tetapi jika semua rute sudah teralokasikan maka proses optimasi penjadwalan sopir pengangkutan sampah telah selesai.

\section{Hasil dan Pembahasan}

Truk sampah dalam pengangkutan sampah di kota Cimahi ini berawal dari garasi dimana semua truk tersimpan, kemudian menuju ke masing-masing TPS sesuai dengan penugasannya, berlanjut ke TPA yang menjadi tempat pembuangan akhir dari semua TPS, kemudian kembali lagi ke garasi.

Data yang diperlukan adalah koordinat garasi, koordinat seluruh TPS, koordinat TPA, rute pengangkutan sampah, jadwal pengangkutan sampah dan jadwal penugasan sopir. Data-data tersebut dapat dilihat pada tabel 3.

Tabel 3. Koordinat Garasi, Koordinat Seluruh TPS, Koordinat TPA, Rute Pengangkutan Sampah, Jadwal Pengangkutan Sampah dan Jadwal Penugasan Sopir

\begin{tabular}{|c|c|c|c|c|c|}
\hline \multirow{2}{*}{ BANGUNAN TPS } & NAMA & JUMLAH & & \multirow{2}{*}{ Latitude } & \multirow{2}{*}{ Longitude } \\
\hline & PENGEMUDI & RITASI & SATUAN & & \\
\hline Garasi & & & & $-6,870567$ & 107,553975 \\
\hline TPS Cilember & Suhara & 2 rit & per-hari & $-6,892743$ & 107,558040 \\
\hline TPS Cilember & Aditya & 1 rit & per-hari & $-6,892743$ & 107,558040 \\
\hline TPS Pasar Atas & Atin & 2 rit & per-hari & $-6,896650$ & 107,543802 \\
\hline TPS Pasar Atas & Janu & 2 rit & per-hari & $-6,896650$ & 107,543802 \\
\hline TPS Pasar Kuda/SPA Sangkuriang & Asep SR & 2 rit & per-hari & $-6,862010$ & 107,542953 \\
\hline TPS Pasar Kuda/SPA Sangkuriang & Obing & 2 rit & per-hari & $-6,862010$ & 107,542953 \\
\hline TPS Pasar Kuda/SPA Sangkuriang & Yono & 2 rit & per-hari & $-6,862010$ & 107,542953 \\
\hline TPS Pemkot & Tio & 1 rit & per-hari & $-6,870590$ & 107,555039 \\
\hline TPST RW 16 & Tio & $2-3$ rit & per-Minggu & $-6,895534$ & 107,553611 \\
\hline TPS Leuwigoong & Budi & 2 rit & per-hari & $-6,880346$ & 107,543069 \\
\hline TPS Leuwigoong & Agus & 2 rit & per-hari & $-6,880346$ & 107,543069 \\
\hline TPS Akses Toll Baros & Jefri & 2 rit & per-hari & $-6,891758$ & 107,542281 \\
\hline TPS Pasar Baros & Ade & 2 rit & per-hari & $-6,890391$ & 107,537140 \\
\hline TPS Santiong Kolmas & Sutiawan & $2-3$ rit & per-Minggu & $-6,849608$ & 107,541593 \\
\hline TPS Mar - Cimol & Atun & $2-3$ rit & per-Minggu & $-6,873320$ & 107,536419 \\
\hline TPS RW 8 Paskal & Suhara RW & $2-3$ rit & per-Minggu & $-6,880876$ & 107,566616 \\
\hline TPS RW 15 Cibodas & Yayan Sopian & $2-3$ rit & per-Minggu & $-6,902027$ & 107,534163 \\
\hline TPS RW 3 Cibeber & Rohim & 2 rit & per-hari & $-6,895831$ & 107,517971 \\
\hline TPS RW 3 Cibeber & Muin & 2 rit & per-hari & $-6,895831$ & 107,517971 \\
\hline TPST RW 14 & Abudin & $2-3$ rit & per-Minggu & $-6,900194$ & 107,529805 \\
\hline TPS Pasar Cimindi & Irman & 2 rit & per-hari & $-6,895016$ & 107,555967 \\
\hline TPS Perum Ratulagi Baros & Abudin & 1 rit & per-Minggu & $-6,892271$ & 107,535241 \\
\hline TPS Perum Armed Kebon Rumput & Yayan Sopian & 1 rit & per-Minggu & $-6,866688$ & 107,540305 \\
\hline TPST RW 4 Patung Gajah & Abudin & 2 rit & per-Minggu & $-6,902320$ & 107,533728 \\
\hline TPS Rw 14 Bratatex & Solihin & 3 rit & per-Minggu & $-6,895068$ & 107,550064 \\
\hline TPA Sarimukti & & & & $-6,680015$ & 107,348673 \\
\hline
\end{tabular}
Sumber: Dinas Lingkungan Hidup Kota Cimahi [8] $\&$ google map.

Berdasarkan data-data koordinat dan dengan menggunakan Harvesine formula maka dapat dihitung jarak antara garasi, setiap TPS dan TPA. Berikut ini adalah persamaan dari Harvesine formula,

$$
\begin{gathered}
a=\sin ^{2}\left(\frac{\Delta \phi}{2}\right)+\cos \phi_{1} \cdot \cos \phi_{2} \cdot \sin ^{2}\left(\frac{\Delta \lambda}{2}\right) \\
c=2 \cdot \operatorname{atan} 2[\sqrt{a}, \sqrt{(1-a)}] \\
d=R \cdot c
\end{gathered}
$$

dimana:

$\phi 1 \quad$ : Latitude titik pertama.

$\phi 2 \quad$ : Latitude titik kedua.

$\lambda 1 \quad$ : Longitude titik pertama.

$\lambda 2$ : Longitude titik kedua. 
$\Delta \phi \quad: \phi 2-\phi 1$

$\Delta \lambda \quad: \lambda 2-\lambda 1$

$\mathrm{R} \quad$ : Radius Bumi $(6371 \mathrm{~km})$.

d : Jarak antar lokasi dilakukan pembulatan ke atas sehingga tidak ada nilai setelah tanda koma, maka diperoleh jarak antara setiap lokasi seperti tersaji pada tabel 4.

Dengan menggunakan Harvesine formula tersebut, serta untuk hasil perhitungan jaraknya

Tabel 4. Jarak Antara Setiap Lokasi (km)

\begin{tabular}{|c|c|c|c|c|c|c|c|c|c|c|c|c|c|c|c|c|c|c|c|c|c|c|c|c|}
\hline No & Bangunan TPS & Latitude & Longitude & 0 & 1 & 2 & 3 & 4 & 5 & 6 & 7 & 8 & 9 & 10 & 11 & 121 & $13 \mid 1$ & 141 & 15 & 16 & 17 & 18 & 19 & 99 \\
\hline 0 & Garasi & 6,870567 & 107,553975 & 0 & 3 & 4 & 2 & 1 & 3 & 2 & 3 & 3 & 3 & 2 & 2 & 5 & 5 & 5 & 3 & 4 & 2 & 5 & 3 & 32 \\
\hline 1 & TPS Cilember & 6,892743 & 107,558040 & 3 & 0 & 2 & 4 & 3 & 1 & 3 & 2 & 3 & 6 & 4 & 2 & 3 & 5 & 4 & 1 & 3 & 4 & 3 & 1 & 34 \\
\hline 27 & TPS Pasar Atas & $-6,896650$ & 107,543802 & 4 & 2 & 0 & 4 & 4 & 2 & 2 & 1 & 2 & 6 & 3 & 4 & 2 & 3 & 2 & 2 & 2 & 4 & 2 & 1 & 33 \\
\hline 37 & TPS Pasar Kuda/S & $-6,862010$ & 107,542953 & 2 & 4 & 4 & 0 & 2 & 4 & 3 & 4 & 4 & 2 & 2 & 4 & 5 & 5 & 5 & 4 & 4 & 1 & 5 & 4 & 30 \\
\hline 47 & TPS Pemkot & $-6,870590$ & 107,555039 & 1 & 3 & 4 & 2 & 0 & 3 & 2 & 3 & 3 & 3 & 3 & 2 & 5 & 5 & 5 & 3 & 4 & 2 & 5 & 3 & 32 \\
\hline 5 & TPST RW 16 & $-6,895534$ & 107,553611 & 3 & 1 & 2 & 4 & 3 & 0 & 3 & 2 & 2 & 6 & 4 & 3 & 3 & 4 & 3 & 1 & 3 & 4 & 3 & 1 & 33 \\
\hline 67 & TPS Leuwigoong & $-6,880346$ & 107,543069 & 2 & 3 & 2 & 3 & 2 & 3 & 0 & 2 & 2 & 4 & 2 & 3 & 3 & 4 & 3 & 3 & 2 & 2 & 3 & 2 & 31 \\
\hline 7 & TPS Akses Toll Ba & $-6,891758$ & 107,542281 & 3 & 2 & 1 & 4 & 3 & 2 & 2 & 0 & 1 & 5 & 3 & 3 & 2 & 3 & 2 & 2 & 1 & 3 & 2 & 1 & 32 \\
\hline 87 & TPS Pa & 391 & 140 & 3 & 3 & 2 & 4 & 3 & 2 & 2 & 1 & 0 & 5 & 2 & 4 & 2 & 3 & 2 & 3 & 1 & 3 & 2 & 2 & 32 \\
\hline 97 & TPS Santiong Kolmas & $-6,849608$ & 107,541593 & 3 & 6 & 6 & 2 & 3 & 6 & 4 & 5 & 5 & 0 & 3 & 5 & 6 & 6 & 6 & 6 & 5 & 2 & 6 & 6 & 29 \\
\hline 10 & TPS Mar - Cimol & $-6,873320$ & 107,536419 & 2 & 4 & 3 & 2 & 3 & 4 & 2 & 3 & 2 & 3 & 0 & 4 & 4 & 4 & 4 & 4 & 3 & 1 & 4 & 3 & 30 \\
\hline 117 & TPS RW 8 Paskal & $-6,880876$ & 107,566616 & 2 & 2 & 4 & 4 & 2 & 3 & 3 & 3 & 4 & 5 & 4 & 0 & 5 & 6 & 5 & 2 & 4 & 4 & 5 & 3 & 33 \\
\hline 127 & TPS RW 15 Cibodas & $-6,902027$ & 107,534163 & 5 & 3 & 2 & 5 & 5 & 3 & 3 & 2 & 2 & 6 & 4 & 5 & 0 & 2 & 1 & 3 & 2 & 4 & 1 & 2 & 33 \\
\hline 13 & TPS RW 3 Cibeber & $-6,895831$ & 107,517971 & 5 & 5 & 3 & 5 & 5 & 4 & 4 & 3 & 3 & 6 & 4 & 6 & 2 & 0 & 2 & 5 & 2 & 5 & 2 & 4 & 31 \\
\hline 147 & TPST RW 14 & $-6,900194$ & 107,529805 & 5 & 4 & 2 & 5 & 5 & 3 & 3 & 2 & 2 & 6 & 4 & 5 & 1 & 2 & 0 & 3 & 2 & 4 & 1 & 3 & 32 \\
\hline 15 & TPS Pasar Cimindi & $-6,895016$ & 107,555967 & 3 & 1 & 2 & 4 & 3 & 1 & 3 & 2 & 3 & 6 & 4 & 2 & 3 & 5 & 3 & 0 & 3 & 4 & 3 & 1 & 34 \\
\hline 167 & TPS Perum Ratulagi Baros & $-6,892271$ & 107,535241 & 4 & 3 & 2 & 4 & 4 & 3 & 2 & 1 & 1 & 5 & 3 & 4 & 2 & 2 & 2 & 3 & 0 & 3 & 2 & 2 & 32 \\
\hline 17 & TPS Perum Armed Kebon Rumput & $-6,866688$ & 107,540305 & 2 & 4 & 4 & 1 & 2 & 4 & 2 & 3 & 3 & 2 & 1 & 4 & 4 & 5 & 4 & 4 & 3 & 0 & 5 & 4 & 30 \\
\hline 187 & TPST RW 4 Patung Gajah & $-6,902320$ & 107,533728 & 5 & 3 & 2 & 5 & 5 & 3 & 3 & 2 & 2 & 6 & 4 & 5 & 1 & 2 & 1 & 3 & 2 & 5 & 0 & 2 & 33 \\
\hline 19 & TPS RW 14 Bratatex & $-6,895068$ & 107,550064 & 3 & 1 & 1 & 4 & 3 & 1 & 2 & 1 & 2 & 6 & 3 & 3 & 2 & 4 & 3 & 1 & 2 & 4 & 2 & 0 & 33 \\
\hline 99 & TPA Sarimukti & $-6,680015$ & 107,348673 & 32 & 34 & 33 & 30 & 32 & 33 & 31 & 32 & 32 & 29 & 30 & \begin{tabular}{|l|}
33 \\
\end{tabular} & 33 & $313^{3}$ & \begin{tabular}{l|l}
32 & 3 \\
\end{tabular} & 34 & 32 & 30 & \begin{tabular}{|l|}
33 \\
\end{tabular} & 33 & o \\
\hline
\end{tabular}

Sumber : Data Diolah, 2020

Berdasarkan data pada tabel 3 dapat diketahui bahwa terdapat 21 orang sopir untuk melayani pengangkutan sampah di 19 TPS. Juga dapat diketahui bahwa ada beberapa TPS yang dilayani oleh lebih dari satu orang sopir, serta ada beberapa sopir yang melayani lebih dari satu TPS, dengan demikian dalam satu hari maksimal ada 21 rute yang bisa dijalankan.
Dikarenakan ada TPS yang jumlah kunjungannya berbeda antara kunjungan minggu pertama dengan kunjungan minggu kedua, maka untuk pengolahan data, periode waktu yang akan digunakan adalah 2 minggu. Dengan demikian rute-rute pengambilan sampah, jadwal pengambilan sampah dan juga jadwal penugasan sopir dapat ditampilkan lebih detil dari tabel sebelumnya (tabel 3) seperti yang tersaji pada tabel 5 . 
Tabel 5. Rute Pengambilan Sampah, Jadwal Pengambilan Sampah dan Penugasan Sopir

\begin{tabular}{|c|c|c|c|c|c|c|c|c|c|c|}
\hline Rute & Supir & Minggu & Hari & Titik 1 & Titik 2 & Titik 3 & Titik 4 & Titik 5 & Titik 6 & Jarak \\
\hline 1 & Suhara & 1,2 & Senin - Minggu & Garasi & TPS Cilember & TPA Sarimukti & TPS Cilember & TPA Sarimukti & Garasi & 137 \\
\hline & Aditya & 1,2 & Senin - Minggu & Garasi & TPS Cilember & TPA Sarimukti & Garasi & & & \\
\hline 3 & Atin & 1,2 & Senin - Minggu & Garasi & TPS Pasar Atas & TPA Sarimukti & TPS Pasar Atas & TPA Sarimukti & Garasi & 135 \\
\hline 4 & Janu & 1,2 & Senin - Minggu & Garasi & TPS Pasar Atas & TPA Sarimukti & TPS Pasar Atas & TPA Sarimukti & Garasi & 135 \\
\hline 5 & Asep SR & 1,2 & Senin - Minggu & Garasi & TPS Pasar Kuda/SPA Sangkuriang & TPA Sarimukti & TPS Pasar Kuda/SPA Sangkuriang & TPA Sarimukti & Garasi & 124 \\
\hline 6 & Obing & 1,2 & Senin-Minggu & Garasi & TPS Pasar Kuda/SPA Sangkuriang & TPA Sarimukti & TPS Pasar Kuda/SPA Sangkuriang & TPA Sarimukti & Garasi & 124 \\
\hline 7 & Yono & 1,2 & Senin - Minggu & Garasi & TPS Pasar Kuda/SPA Sangkuriang & TPA Sarimukti & TPS Pasar Kuda/SPA Sangkuriang & TPA Sarimukti & Garasi & 124 \\
\hline 8 & Tio & 1,2 & Senin - Minggu & Garasi & TPS Pemkot & TPA Sarimukti & Garasi & & & 65 \\
\hline 9 & Tio & 1 & Kamis \& Minggu & Garasi & TPST RW 16 & TPA Sarimukti & Garasi & & & 68 \\
\hline 10 & Tio & 2 & Senin, Kamis \& Minggu & Garasi & TPST RW 16 & TPA Sarimukti & Garasi & & & \\
\hline 11 & Budi & 1,2 & Senin - Minggu & Garasi & TPS Leuwigoong & TPA Sarimukti & TPS Leuwigoong & TPA Sarimukti & Garasi & 127 \\
\hline 12 & Agus & 1,2 & Senin - Minggu & Garasi & TPS Leuwigoong & TPA Sarimukti & TPS Leuwigoong & TPA Sarimukti & Garasi & 127 \\
\hline 13 & Jefri & 1,2 & Senin-Minggu & Garasi & TPS Akses Toll Baros & TPA Sarimukti & TPS Akses Toll Baros & TPA Sarimukti & Garasi & 131 \\
\hline 14 & Ade & 1,2 & Senin - Minggu & Garasi & TPS Pasar Baros & TPA Sarimukti & TPS Pasar Baros & TPA Sarimukti & Garasi & 131 \\
\hline 15 & Sutiawan & 1 & Kamis \& Minggu & Garasi & TPS Santiong Kolmas & TPA Sarimukti & Garasi & & & 64 \\
\hline 16 & Sutiawan & 2 & Senin, Kamis \& Minggu & Garasi & TPS Santiong Kolmas & TPA Sarimukti & Garasi & & & 64 \\
\hline 17 & Atun & 1 & Kamis \& Minggu & Garasi & TPS Mar - Cimol & TPA Sarimukti & Garasi & & & 64 \\
\hline 18 & \begin{tabular}{|l|} 
Atun \\
\end{tabular} & & Senin, Kamis \& Minggu & Garasi & TPS Mar - Cimol & TPA Sarimukti & Garasi & & & 64 \\
\hline 19 & Suhara RW & 1 & Kamis \& Minggu & Garasi & TPS RW 8 Paskal & TPA Sarimukti & Garasi & & & 67 \\
\hline 20 & Suhara RW & 2 & Senin, Kamis \& Minggu & Garasi & TPS RW 8 Paskal & TPA Sarimukti & Garasi & & & 67 \\
\hline 21 & Yayan Sopian & 1 & Kamis \& Minggu & Garasi & TPS RW 15 Cibodas & TPA Sarimukti & Garasi & & & 70 \\
\hline 22 & Yayan Sopian & 2 & Senin, Kamis \& Minggu & Garasi & TPS RW 15 Cibodas & TPA Sarimukti & Garasi & & & 70 \\
\hline 23 & Rohim & 1,2 & Selasa \& Sabtu & Garasi & TPS RW 3 Cibeber & TPA Sarimukti & TPS RW 3 Cibeber & TPA Sarimukti & Garasi & 130 \\
\hline 24 & Muin & 1,2 & Selasa \& Sabtu & Garasi & TPS RW 3 Cibeber & TPA Sarimukti & TPS RW 3 Cibeber & TPA Sarimukti & Garasi & 130 \\
\hline 25 & Abudin & 1 & Kamis \& Minggu & Garasi & TPST RW 14 & TPA Sarimukti & Garasi & & & 69 \\
\hline 26 & Abudin & 2 & Senin, Kamis \& Minggu & Garasi & TPST RW 14 & TPA Sarimukti & Garasi & & & \\
\hline 27 & Irman & 1,2 & Senin - Minggu & Garasi & TPS Pasar Cimindi & TPA Sarimukti & TPS Pasar Cimindi & TPA Sarimukti & Garasi & 137 \\
\hline 28 & Abudin & 1,2 & Rabu & Garasi & TPS Perum Ratulagi Baros & TPA Sarimukti & Garasi & & & 68 \\
\hline 29 & Yayan Sopian & 1,2 & Rabu & Garasi & TPS Perum Armed Kebon Rumput & TPA Sarimukti & Garasi & & & 64 \\
\hline 30 & Abudin & 1,2 & Selasa \& Sabtu & Garasi & TPST RW 4 Patung Gajah & TPA Sarimukti & Garasi & & & \\
\hline 31 & Solihin & 1,2 & Senin, Rabu \& Jumat & Garasi & TPS Rw 14 Bratatex & TPA Sarimukti & Garasi & & & 68 \\
\hline
\end{tabular}

Sumber : Data Diolah, 2020

Sekarang kita dapat mengetahui jarak tempuh yang harus dilalui oleh setiap sopir pada setiap 2 minggunya. Jarak tempuh masingmasing sopir dapat dilihat pada tabel 6 .

Tabel 6. Jarak Tempuh Setiap Sopir pada Setiap 2 Minggu (Km)

\begin{tabular}{|l|c|c|c|c|c|c|c|c|c|c|c|c|c|c|c|}
\hline Supir \Hari & Senin & Selasa & Rabu & Kamis & Jumat & Sabtu & Minggu & Senin & Selasa & Rabu & Kamis & Jumat & Sabtu & Minggu & Jumlah \\
\hline Abudin & 0 & 70 & 68 & 69 & 0 & 70 & 69 & 69 & 70 & 68 & 69 & 0 & 70 & 69 & 761 \\
\hline Ade & 131 & 131 & 131 & 131 & 131 & 131 & 131 & 131 & 131 & 131 & 131 & 131 & 131 & 131 & 1834 \\
\hline Aditya & 69 & 69 & 69 & 69 & 69 & 69 & 69 & 69 & 69 & 69 & 69 & 69 & 69 & 69 & 966 \\
\hline Agus & 127 & 127 & 127 & 127 & 127 & 127 & 127 & 127 & 127 & 127 & 127 & 127 & 127 & 127 & 1778 \\
\hline Asep SR & 124 & 124 & 124 & 124 & 124 & 124 & 124 & 124 & 124 & 124 & 124 & 124 & 124 & 124 & 1736 \\
\hline Atin & 135 & 135 & 135 & 135 & 135 & 135 & 135 & 135 & 135 & 135 & 135 & 135 & 135 & 135 & 1890 \\
\hline Atun & 0 & 0 & 0 & 64 & 0 & 0 & 64 & 64 & 0 & 0 & 64 & 0 & 0 & 64 & 320 \\
\hline Budi & 127 & 127 & 127 & 127 & 127 & 127 & 127 & 127 & 127 & 127 & 127 & 127 & 127 & 127 & 1778 \\
\hline Irman & 137 & 137 & 137 & 137 & 137 & 137 & 137 & 137 & 137 & 137 & 137 & 137 & 137 & 137 & 1918 \\
\hline Janu & 135 & 135 & 135 & 135 & 135 & 135 & 135 & 135 & 135 & 135 & 135 & 135 & 135 & 135 & 1890 \\
\hline Jefri & 131 & 131 & 131 & 131 & 131 & 131 & 131 & 131 & 131 & 131 & 131 & 131 & 131 & 131 & 1834 \\
\hline Muin & 0 & 130 & 0 & 0 & 0 & 130 & 0 & 0 & 130 & 0 & 0 & 0 & 130 & 0 & 520 \\
\hline Obing & 124 & 124 & 124 & 124 & 124 & 124 & 124 & 124 & 124 & 124 & 124 & 124 & 124 & 124 & 1736 \\
\hline Rohim & 0 & 130 & 0 & 0 & 0 & 130 & 0 & 0 & 130 & 0 & 0 & 0 & 130 & 0 & 520 \\
\hline Solihin & 68 & 0 & 68 & 0 & 68 & 0 & 0 & 68 & 0 & 68 & 0 & 68 & 0 & 0 & 408 \\
\hline Suhara & 137 & 137 & 137 & 137 & 137 & 137 & 137 & 137 & 137 & 137 & 137 & 137 & 137 & 137 & 1918 \\
\hline Suhara RW & 0 & 0 & 0 & 67 & 0 & 0 & 67 & 67 & 0 & 0 & 67 & 0 & 0 & 67 & 335 \\
\hline Sutiawan & 0 & 0 & 0 & 64 & 0 & 0 & 64 & 64 & 0 & 0 & 64 & 0 & 0 & 64 & 320 \\
\hline Tio & 65 & 65 & 65 & 133 & 65 & 65 & 133 & 133 & 65 & 65 & 133 & 65 & 65 & 133 & 1250 \\
\hline Yayan Sopian & 0 & 0 & 64 & 70 & 0 & 0 & 70 & 70 & 0 & 64 & 70 & 0 & 0 & 70 & 478 \\
\hline Yono & 124 & 124 & 124 & 124 & 124 & 124 & 124 & 124 & 124 & 124 & 124 & 124 & 124 & 124 & 1736 \\
\hline
\end{tabular}

Sumber : Data Diolah, 2020

Berdasarkan hasil perhitungan yang tersaji pada tabel 6 dapat diketahui bahwa sopir dengan jarak tempuh terjauh adalah Irman \& Suhara yang setiap 2 minggunya menempuh jarak sejauh 1918 Km. Serta jarak terpendek adalah Atun \& Sutiawan yang setiap minggunya harus menempuh jarak sejauh 320
Km. Dengan demikian terjadi kesenjangan sebesar $1598 \mathrm{Km}$. Berdasarkan tujuan dari penelitian ini adalah untuk meminimalkan ketidakmerataan jarak tempuh setiap sopir, maka untuk penelitian kali ini akan digunakan Greedy Algorithm untuk melakukan penjadwalan ulang sopir dalam menjalankan 
rute-rute pengambilan sampah setiap harinya. Jika pada penjadwalan sebelumnya, terjadi spesialisasi rute, dimana seorang sopir hanya akan terus menjalankan sebuah rute yang sama setiap waktunya, pada penjadwalan ulang kali ini tidak ada spesialisasi rute, jadi setiap sopir pada setiap hari akan menjalankan rute-rute yang berbeda. Greedy Algorithm ini bekerja berdasarkan konsep keserakahan, dimana pemilihan keputusan adalah memilih yang terbaik pada saat itu, tanpa memikirkan pilihan pada waktu berikutnya. Penerapan konsep keserakahan ini pada penjadwalan ulang sopir ini adalah dimana sopir yang memilikki jarak tempuh terjauh saat ini, akan memilih rute yang paling pendek untuk hari berikutnya. Sopir yang memilikki jarak tempuh terjauh kedua, akan memilihi rute paling pendek kedua untuk hari berikutnya. Pola pemilihan rute ini akan dilakukan untuk sopir-sopir lainnya. Berdasarkan jarak tempuh setiap sopir pada tabel 6 maka jarak tempuh setiap sopir dapat diberikan ranking berdasarkan jarak tempuh terjauh dan dapat ditentukan rute selanjutnya berdasarkan ranking jarak setiap rute. Hasil pemberian ranking jarak tempuh dan penentuan penugasan rute untuk hari Senin di Minggu 1 dapat dilihat pada tabel 7 .

Tabel 7. Ranking Jarak Tempuh Setiap Sopir pada Setiap 2 Minggu (Km)

\begin{tabular}{|c|c|c|c|c|c|c|c|c|}
\hline \multirow[b]{2}{*}{ Supir } & \multicolumn{3}{|r|}{ Awal } & \multicolumn{5}{|c|}{ Senin } \\
\hline & Jumlah & Ranking & Ranking Rute Selanjutnya & Rute & Jarak. & Jumlah & Rank & Rank of Next Route \\
\hline Abudin & 761 & 14 & 8 & 12 & 127 & 127 & 7 & 14 \\
\hline Ade & 1834 & 5 & 16 & 0 & 0 & 0 & 15 & 1 \\
\hline Aditya & 966 & 13 & 9 & 5 & 124 & 124 & 9 & 11 \\
\hline Agus & 1778 & 7 & 14 & 8 & 65 & 65 & 14 & 8 \\
\hline Asep SR & 1736 & 9 & 11 & 7 & 124 & 124 & 10 & 12 \\
\hline Atin & 1890 & 3 & 18 & 0 & 0 & 0 & 16 & 2 \\
\hline Atun & 320 & 20 & 1 & 1 & 137 & 137 & 1 & 20 \\
\hline Budi & 1778 & 8 & 15 & 0 & 0 & 0 & 17 & 3 \\
\hline Irman & 1918 & 1 & 20 & 0 & 0 & 0 & 18 & 4 \\
\hline Janu & 1890 & 4 & 19 & 0 & 0 & 0 & 19 & 5 \\
\hline Jefri & 1834 & 6 & 17 & 0 & 0 & 0 & 20 & 6 \\
\hline Muin & 520 & 15 & 6 & 14 & 131 & 131 & 5 & 16 \\
\hline Obing & 1736 & 10 & 12 & 2 & 69 & 69 & 12 & 10 \\
\hline Rohim & 520 & 16 & 7 & 11 & 127 & 127 & 8 & 15 \\
\hline Solihin & 408 & 18 & 4 & 4 & 135 & 135 & 3 & 18 \\
\hline Suhara & 1918 & 2 & 21 & 0 & 0 & 0 & 21 & 7 \\
\hline Suhara RW & 335 & 19 & 3 & 3 & 135 & 135 & 4 & 19 \\
\hline Sutiawan & 320 & 21 & 2 & 27 & 137 & 137 & 2 & 21 \\
\hline Tio & 1250 & 12 & 10 & 6 & 124 & 124 & 11 & 13 \\
\hline Yayan Sopian & 478 & 17 & 5 & 13 & 131 & 131 & 6 & 17 \\
\hline Yono & 1736 & 11 & 13 & 31 & 68 & 68 & 13 & 9 \\
\hline
\end{tabular}

Sumber : Data Diolah, 2020

Pada tabel 7 dapat dilihat bahwa Irman \& Suhara memilikki ranking tertinggi berdasarkan jarak tempuh dari hasil jadwal sebelumnya yaitu sejauh 1918 Km, maka Irman \& Suhara pada hari Senin di Minggu 1 akan mendapatkan rute dengan ranking terendah. Karena pada hari Senin di Minggu 1 hanya ada 14 rute, maka Irman \& Suhara tidak menjalankan rute pada hari Senin di Minggu 1. Sementara Atun \& Sutiawan memilikki ranking terendah yaitu sejauh $320 \mathrm{Km}$, maka mereka pada hari Senin di Minggu 1 akan mendapatkan rute dengan ranking tertinggi, yaitu rute 1 dan 27 yang masing-masing jarak tempuhnya $137 \mathrm{~km}$. Dengan cara yang sama maka dapat ditentukan penugasan rute untuk hari Selasa di Minggu 1 dan hari-hari selanjutnya. Hasil penentuan semua penugasan rute untuk seluruh sopir setiap 2 minggunya dapat dlihat pada tabel 8 . 
Tabel 8. Hasil Penjadwalan Ulang Sopir Pengangkut Sampah

\begin{tabular}{|c|c|c|c|c|c|c|c|c|c|c|c|c|c|c|c|c|c|c|c|}
\hline \multirow{2}{*}{\multicolumn{5}{|c|}{ Awal }} & \multirow{2}{*}{\multicolumn{5}{|c|}{$\begin{array}{l}\text { Senin } \\
\text { Jumat }\end{array}$}} & \multirow{2}{*}{\multicolumn{5}{|c|}{$\begin{array}{l}\text { Selasa } \\
\text { Sabtu }\end{array}$}} & \multirow{2}{*}{\multicolumn{5}{|c|}{$\begin{array}{r}\text { Rabu } \\
\text { Minggu }\end{array}$}} \\
\hline & & & & & & & & & & & & & & & & & & & \\
\hline Rute & \multicolumn{4}{|c|}{\begin{tabular}{l|l|l|l|l|}
\multicolumn{3}{|c}{ Kamis } \\
Rute & Jarak \\
Jumlah & Rank & Rank of Next Route
\end{tabular}} & Rute & Jarak & \begin{tabular}{|l|} 
Jumlah \\
\end{tabular} & Rank & Rank of Next Route & Rute & Jarak & Jumlah & Rank & Rank of Next Route & Rute & Jarak & Jumlah & Rank & Rank of Next Route \\
\hline 27 & \begin{tabular}{|l|}
137 \\
\end{tabular} & 334 & 10 & 12 & 2 & 69 & \begin{tabular}{|l|}
403 \\
\end{tabular} & 14 & 8 & \begin{tabular}{|l|}
34 \\
\end{tabular} & 130 & 533 & 3 & 18 & 15 & 64 & 597 & 10 & \\
\hline 12 & 127 & 388 & 1 & 21 & 0 & 0 & 388 & 15 & 7 & 23 & 130 & 518 & 13 & 8 & 12 & 127 & 645 & 2 & 20 \\
\hline 4 & 135 & 383 & 6 & 16 & 0 & 0 & 383 & 20 & 2 & 27 & 137 & 520 & 10 & 10 & 6 & 124 & 644 & 3 & 18 \\
\hline 25 & 69 & 332 & 13 & 8 & 12 & 127 & 459 & 5 & 17 & 0 & 0 & 459 & 21 & 1 & 1 & 137 & 596 & 14 & 7 \\
\hline 13 & 131 & 379 & 7 & 14 & 8 & 65 & 444 & 10 & 12 & 6 & 124 & 568 & 2 & 20 & 0 & 0 & 568 & 21 & 1 \\
\hline 5 & 124 & 385 & 3 & 17 & 0 & 0 & 385 & 17 & 3 & 3 & 135 & 520 & 11 & 11 & 7 & 124 & 644 & 4 & 19 \\
\hline 6 & 124 & 385 & 4 & 18 & 0 & 0 & 385 & 18 & 4 & 4 & 135 & 520 & 12 & 12 & 21 & 70 & 590 & 19 & 3 \\
\hline 19 & 67 & 333 & 11 & 10 & 6 & 124 & 457 & 7 & 14 & 30 & 70 & 527 & 7 & 15 & 9 & 68 & 595 & 16 & 5 \\
\hline 8 & 65 & 331 & 15 & 5 & 13 & 131 & 462 & 3 & 18 & $\begin{array}{ll}3 \\
\end{array}$ & 0 & 462 & 19 & 2 & 27 & 137 & 599 & 8 & 14 \\
\hline 0 & 0 & 268 & 20 & 2 & 27 & 137 & 405 & 12 & 10 & 12 & 127 & 532 & 5 & 17 & 8 & 65 & 597 & 11 & 10 \\
\hline 15 & 64 & 330 & 18 & 3 & 3 & 135 & 465 & 1 & 20 & 0 & 0 & 465 & 17 & 4 & 4 & 135 & 600 & 7 & 15 \\
\hline 7 & 124 & 385 & 5 & 19 & 0 & 0 & 385 & 19 & 5 & 513 & 131 & 516 & 15 & 6 & 14 & 131 & 647 & 1 & 21 \\
\hline 11 & 127 & 387 & 2 & 20 & 0 & 0 & 387 & 16 & 6 & \begin{tabular}{|l|l|}
5 & 14 \\
\end{tabular} & 131 & 518 & 14 & 9 & 5 & 124 & 642 & 6 & 16 \\
\hline 1 & 137 & 333 & 12 & 11 & 7 & 124 & 457 & 8 & 15 & 5 & 69 & 526 & 8 & 14 & 25 & 69 & 595 & 17 & 6 \\
\hline 21 & 70 & 332 & 14 & 9 & 5 & 124 & \begin{tabular}{ll|}
456 \\
\end{tabular} & 9 & 13 & 7 & 124 & 580 & 1 & 21 & 0 & 0 & 580 & 20 & 2 \\
\hline 0 & 0 & 267 & 21 & 1 & 1 & 137 & 404 & 13 & $\begin{array}{ll}9 \\
\end{array}$ & 11 & 127 & 531 & 6 & 16 & 19 & 67 & 598 & 9 & 13 \\
\hline 2 & 69 & 331 & 16 & 6 & 14 & 131 & 462 & 4 & 19 & 0 & 0 & 462 & 20 & 3 & 3 & 135 & 597 & 12 & 11 \\
\hline 3 & 135 & 341 & 9 & 13 & 31 & 68 & 409 & 11 & 11 & 5 & 124 & 533 & 4 & 19 & 17 & 64 & 597 & 13 & 12 \\
\hline 14 & 131 & 379 & 8 & 15 & 0 & 0 & 379 & 21 & 1 & 1 & 137 & 516 & 16 & 7 & 11 & 127 & 643 & 5 & 17 \\
\hline 17 & 64 & 330 & 19 & 4 & 4 & $\begin{array}{l}135 \\
\end{array}$ & $\begin{array}{ll}465 \\
\end{array}$ & 2 & 21 & 0 & 0 & 465 & 18 & 5 & 13 & 131 & 596 & 15 & 8 \\
\hline 9 & \begin{tabular}{|l|}
68 \\
\end{tabular} & 331 & 17 & 7 & 11 & 127 & 458 & 6 & 16 & 8 & 65 & 523 & 9 & 13 & 2 & 69 & 592 & 18 & 4 \\
\hline
\end{tabular}

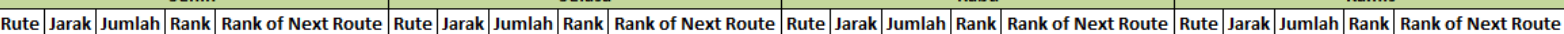

\begin{tabular}{|c|c|c|c|c|c|c|c|c|c|c|c|c|c|c|c|c|c|c|c|}
\hline & & & & & & & & & & & & & & & & & & & \\
\hline 5 & 124 & 721 & 7 & 13 & 7 & 124 & 845 & 1 & 21 & 0 & 0 & 845 & 17 & 5 & \begin{tabular}{l|l|}
5 & 13 \\
\end{tabular} & 131 & 976 & 11 & 10 \\
\hline 18 & 64 & 709 & 13 & 8 & 24 & 130 & 839 & 3 & 19 & 0 & 0 & 839 & 19 & 3 & 3 & 135 & 974 & 14 & 7 \\
\hline 8 & 65 & 709 & 14 & 9 & 11 & 127 & 836 & 6 & 15 & 8 & 65 & 901 & 8 & 14 & \begin{tabular}{l|l|}
4 & 26 \\
\end{tabular} & 69 & 970 & 16 & 5 \\
\hline 11 & 127 & 723 & 5 & 16 & 8 & 65 & 788 & 15 & 7 & 11 & 127 & 915 & 4 & 16 & 20 & 67 & 982 & 7 & 15 \\
\hline 1 & 137 & 705 & 16 & 6 & 14 & 131 & 836 & 7 & 16 & 29 & 64 & 900 & 9 & 13 & 2 & 69 & 969 & 18 & 4 \\
\hline 16 & 64 & 708 & 15 & 7 & 23 & 130 & 838 & 4 & 18 & 0 & 0 & 838 & 20 & 2 & 27 & 137 & 975 & 13 & 9 \\
\hline 3 & 135 & 725 & 4 & 18 & 0 & 0 & 725 & 20 & 2 & 27 & 137 & 862 & 12 & 10 & 6 & 124 & 986 & 5 & 17 \\
\hline 13 & 131 & 726 & 2 & 19 & 0 & 0 & 726 & 18 & 3. & 3 & 135 & 861 & 13 & 8 & \begin{tabular}{l|l}
8 & 12 \\
\end{tabular} & 127 & 988 & 3 & 19 \\
\hline 26 & 69 & 668 & 17 & 4 & 4 & 135 & 803 & 10 & 12 & 2 & 69 & 872 & 10 & 11 & 7 & 124 & 996 & 1 & 21 \\
\hline 6 & 124 & 721 & 8 & 14 & 30 & 70 & 791 & 13 & 9 & 5 & 124 & 915 & 5 & 17 & 8 & 65 & 980 & 9 & 13 \\
\hline 31 & 68 & 668 & 18 & 5 & 13 & 131 & 799 & 12 & 10 & 6 & 124 & 923 & 2 & 20 & 0 & 0 & 923 & 21 & 1 \\
\hline 0 & 0 & 647 & 21 & 1 & 1 & 137 & 784 & 16 & 6 & 14 & 131 & 915 & 6 & 18 & \begin{tabular}{l|l}
8 & 16 \\
\end{tabular} & 64 & 979 & 10 & 12 \\
\hline 10 & 68 & 710 & 11 & 10 & 12 & 127 & 837 & 5 & 17 & 0 & 0 & 837 & 21 & 1 & 1 & 137 & 974 & 15 & 8 \\
\hline 14 & 131 & 726 & 3 & 20 & 0 & 0 & 726 & 19 & 4 & 4 & 135 & 861 & 14 & 9 & 5 & 124 & 985 & 6 & 16 \\
\hline 27 & 137 & 717 & 10 & 12 & 6 & 124 & 841 & 2 & 20 & 0 & 0 & 841 & 18 & 4 & 4 & 135 & 976 & 12 & 11 \\
\hline 2 & 69 & 667 & 19 & 2 & 27 & 137 & 804 & 9 & 13 & 28 & 68 & 872 & 11 & 12 & 22 & 70 & 942 & 19 & 3 \\
\hline 7 & 124 & 721 & 9 & 15 & 2 & 69 & 790 & 14 & 8 & 12 & 127 & 917 & 3 & 19 & 18 & 64 & 981 & 8 & 14 \\
\hline 22 & 70 & 667 & 20 & 3 & 3 & 135 & 802 & 11 & 11 & 7 & 124 & 926 & 1 & 21 & 0 & 0 & 926 & 20 & 2 \\
\hline 20 & 67 & 710 & 12 & 11 & 5 & 124 & 834 & 8 & 14 & 31 & 68 & 902 & 7 & 15 & 10 & 68 & 970 & 17 & 6 \\
\hline 12 & 127 & 723 & 6 & 17 & 0 & 0 & 723 & 21 & 1 & 1 & 137 & 860 & 15 & 7 & 11 & 127 & 987 & 4 & 18 \\
\hline 4 & 135 & 727 & 1 & 21 & 0 & 0 & 727 & 17 & 5 & $5 \mid 13$ & 131 & 858 & 16 & 6 & \begin{tabular}{l|l}
6 & 14 \\
\end{tabular} & 131 & 989 & 2 & 20 \\
\hline
\end{tabular}

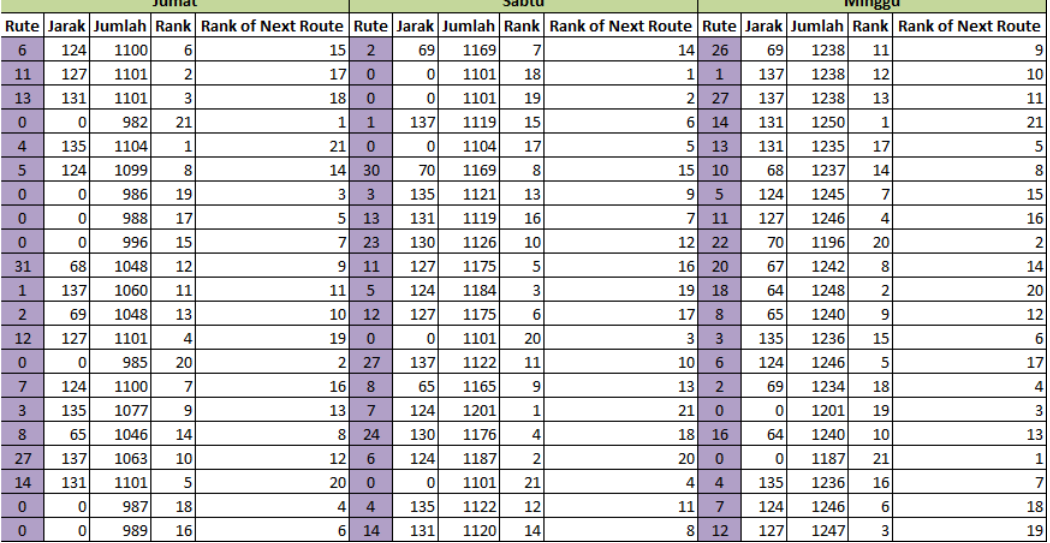

Sumber : Data Diolah, 2020

Berdasarkan hasil perhitungan yang tersaji pada tabel 8 terlihat bahwa setelah dilakukan jadwal ulang, sopir yang memilikki jarak tempuh terjauh adalah Agus dengan jarak tempuh $1250 \mathrm{Km}$ dan sopir dengan jarak tempuh terpendek adalah Sutiawan dengan jarak tempuh 1187. Dengan demikian kesenjangan jarak tempuh yang terjadi hanya 63 $\mathrm{Km}$ saja. Kesenjangan ini tentu lebih baik dibandingkan dengan penjadwalan sebelumnya yang mencapai $1598 \mathrm{~km}$.

\section{Kesimpulan dan Saran}

Berdasarkan hasil pengolahan data, dapat disimpulkan bahwa Greedy Algorithm dapat dijadikan alternatif yang baik untuk menyelesaikan kasus penjadwalan karena mudah digunakan, komputasi cepat dan 
memberikan hasil yang baik. Penelitian sebelumnya hanya membahas kasus optimasi beban kerja sopir dengan tujuan meminimumkan biaya. dimana metode yang digunakannya adalah integer programming. Pada penelitian ini, terlihat bahwa jika menggunakan jadwal sebelumnya terjadi kesenjangan sebesar $1598 \mathrm{~km}$, sedangkan setelah dilakukan penjadwalan ulang dengan menggunakan Greedy Algorithm terjadi kesenjangan sebesar $63 \mathrm{~km}$. Tentunya ini menunjukkan terjadi penurunan kesenjangan yang cukup signifikan yaitu sebesar $1535 \mathrm{~km}$ atau sebesar $96 \%$.

Kekurangan pada penelitian ini adalah periode waktu yang digunakan berkisar 2 minggu. Tentunya hal ini bisa menjadi peluang untuk penelitian selanjutnya dengan memperlebar periode waktu yang digunakan, misalnya menjadi 1 bulan. Hal ini diharapkan dengan terjadinya pelebaran periode waktu, kesenjangan jarak tempuh sopir bisa lebih kecil, walaupun Greedy Algorithm dapat memberikan hasil yang baik, bukan berarti tidak ada peluang untuk mendapatkan hasil yang lebih baik. Selain itu, penelitian selanjutnya dapat mengembangkan metode dengan penggunaan metaheuristik pada kasus penjadwalan sopir ini. Pengembangan metode tersebut dapat menjadi sebuah tema untuk penelitian selanjutnya dan diharapkan bisa memberikan hasil yang lebih baik.

\section{Daftar Pustaka}

[1] B. P. Statistik, Statistik Daerah Kota Cimahi. Cimahi: Badan Pusat Statistik, 2019.

[2] Sibima.pu.go.id, "Spesifikasi Teknis Sektor Persampahan," ed, 2019.

[3] Erna, Bisma, and Guslan, "Penentuan Lokasi TPA menggunakan metode Cluster di Kota Cimahi; competitive," vol. 13, 2018.

[4] G. Ghiani, E. Guerriero, A. Manni, E. Manni, and A. Potenza, "Simultaneous personnel and vehicle shift scheduling in the waste management sector," Waste management, vol. 33, pp. 1589-1594, 2013.

[5] E.-G. Talbi, Metaheuristics: from design to implementation vol. 74: John Wiley \& Sons, 2009.
[6] M. Z. Usman and T. Oktiarso, "Implementasi Algoritma Greedy Untuk Menyelesaikan Travelling Salesman Problem di Distributor PT. Z," Journal of Integrated System, vol. 1, pp. 216-229, 2018.

[7] R. H. D. Putra, H. Sujaini, and N. Safriadi, "Penerapan Metode Haversine Formula Pada Sistem Informasi Geografis Pengukuran Luas Tanah," JUSTIN (Jurnal Sistem dan Teknologi Informasi), vol. 4, pp. 157-162, 2015.

[8] D. L. H. K. Cimahi, "Data Jumlah Produksi Sampah," ed, 2020.

[9] Nida Salma Fauziyah \& Agus Yodi Gunawan, "Optimisasi Penjadwalan Kerja Sopir Di Agen Perjalanan" FMIPA-ITB, 2020.

[10] Muhammad Fakhri Azhari, Amril Aman \& Prapto Tri Supriyo "Penjadwalan Sopir Bus Menggunakan Integer Programming: Studi Kasus Di Bus Transpakuan" FMIPA-IPB, 2015.

[11] Mega Conti Putri Belikha "Pembuatan Sistem Informasi Penjadwalan Sopir, Pemesanan dan Persewaan Mobil Pada Rental Mobil X" FT-Universitas Surabaya, 2012.

[12] N. K. Dewi and A. S. Putra, "Penerimaan Karyawan Baru Dengan," VISUALIKA, vol. 6, no. 2, pp. 154-160, 2020.

[13] F. D. Putra, Zulfikar, and A. Sifaunajah, "Penerapan Algoritma Greedy Untuk Prediksi Efektifitas Penggunaan Daya Listrik," JSAI (Journal Sci. Appl. Informatics), vol. 3, no. 3, pp. 163-174, 2020.

[14] Z. M. Jofie, S. Bahri, and A. Baqi, Iqbal, "Aplikasi Algoritma Greedy Untuk Pewarnaan Wilayah Pada Peta Kota Padang Berbasis Teorema Empat Warna," Matematika, vol. IX, no. 4, pp. 294-301, 2011.

[15] H. Irwan, "Optimasi Penjadwalan Job Shop dengan Metode Algoritma Greedy," Profisiensi, vol. 8, no. 2, pp. 164-176, 2020. 